UDC 378.14

DOI: $10.52534 / \mathrm{msu}-$ pp.7(4).2021.20-29

\author{
Liliia V. Huzar ${ }^{\star}$ \\ Taras Shevchenko National University of Kyiv \\ 01033, 60 Volodymyrska Str., Kyiv, Ukraine
}

\title{
Efficiency of Students' Independent Work: The Problem and Ways to Improve
}

\section{Article's History: \\ Received: 28.09.2021 \\ Revised: 29.10 .2021 \\ Accepted: 01.11.2021}

\section{Suggested Citation:}

Huzar, L.V. (2021). Efficiency of students' independent work: The problem and ways to improve. Scientific Bulletin of Mukachevo State University. Series "Pedagogyand Psychology", 7(4), 20-29.

*Corresponding author

\begin{abstract}
The relevance of the study is due to the importance of the problem of educating professionals and specialists who can think critically and independently becomes in modern society. The amount of information and knowledge increase that a student should learn. In higher education institutions, there is an objective need to pay more attention to the independent work of students to contribute to their effective and effective professional development. To preserve and improve the effectiveness of learning, educational institutions should strive to find new ways to use the educational process to organize independent work of students. In this regard, the author's article is aimed at determining the essence and features of independent work of students, ways to implement it and principles for improving performance in higher educational institutions. The leading methods of research of this problem are methods of analysis, synthesis, deduction, generalization and comparison, which helped to determine the main essence of independent work of students and the problems of this component of learning. The article presents various approaches to the study and interpretation of the process of independent work of students; analyzed the work of teachers, researchers who deal with the problem of motivation and improving the effectiveness of this type of activity; focused on the difficulties and features of its organization; proposed various methods and methods to optimize this process; described the aspects of successful implementation of this stage of training; diagnosed the problems that the student faces during the performance of independent work; determined the levels of this activity (reproductive (training), reconstructive and creative search); demonstrated the latest information technology approaches to the organization of independent educational activities of students; diagnosed the effectiveness of independent work in the learning process based on the assimilation of educational material, monitoring of educational and cognitive activity of students; recommendations and requirements for improving the effectiveness of independent work are revealed. The materials of the article are of practical and theoretical value for students, as they contribute to the development of their initiative and professional independence. In addition, the information may be relevant for future teachers, scientists, and teachers who will be able to adjust tasks according to the individual characteristics of students and systematically monitor the educational process
\end{abstract}

Keywords: professional development, initiative, extracurricular independent work, creative independent work, independence

\section{INTRODUCTION}

Nowadays, the interest of teachers and scientists in the activities of higher educational institutions and in the problems of organizing independent work of students in particular has been increasing. This can be justified by the fact that the amount of knowledge that students need to learn is growing and constantly updated [1]. Special attention is paid to the independence of students, which is due 
to the development of an innovative strategy for organizing training.

The problem of organizing independent learning activities has become important in the context of changing educational paradigms, where knowledge is obtained once, before education through life, that is, systematic and continuous development [2]. Most educational institutions believe that the priority in training future specialists is the development of a creative, active and independent personality who will have an interest in knowledge. This will contribute to professionally-oriented motives for educational activities. Today, quite often students are passive about classes, and their cognitive activity is at a low level. They listen to lecturers, write down educational material, but do not even want to try to understand it on their own. However, it is important that students move to the position of independence in time and activate the process of perception of knowledge during the organization of the educational process.

In the modern world, it is quite common to hear the opinion that a future professional should think outside the box. This is honed in the process of independent work. Such a trait as independence becomes professionally necessary for any specialist. It is in institutions of higher education that the mandatory process of mastering the methods of independent acquisition of knowledge and their further creative use should take place. As a result, the individual will become open to everything new and will have a progressive intelligence [3]. Independence is the most important professional and mental trait that describes the ability to systematize, design and regulate one's activities without the direct influence of guidance and practical help. Having mastered the experience of independent activity, the student will be able to form their knowledge, develop creative skills not only in the university, but also in further work. The ability to work independently, process information and apply their knowledge become a fundamental prerequisite for the effective formation of students' professional independence and effective learning [4].

The relevance of the study resides in a wide range of requirements, which the education system applies to university graduates. Student training has its own specific character, where teachers do not provide ready-made knowledge, but contribute to the formation of students' independent search for it. A modern teacher only directs the learning process and the stage of assimilation of knowledge [5]. Scientists note that higher education institutions strive to create an independent creative personality of students [6]. Since the amount of data and information is constantly increasing, and students need to process a large amount of content, ways can be used to make this process more interesting and intensive. The latest technologies require young professionals to be active, educated, independent and confident. They must adapt well to new living conditions and be socially oriented. This is what makes the problem of independent work of students so important.

The purpose of the article is about revealing the essence of independent work and possible ways to conduct it.
The author reveals various approaches to the study and interpretation of the problem of independent work of students; shows the results of an analysis of researchers' work; focuses on the problems of organizing this activity; suggests various forms of work to improve this process; describes aspects of successful implementation of this stage of training; diagnoses the levels of independence of students; reveals the requirements for improving independent work.

\section{MATERIALS AND METHODS}

In the process of research, the following methods were used: theoretical methods (study and analysis of pedagogical, psychological, methodological literature on the research topic; analysis of features and problems of students' independence; generalization of theoretical material on the studied issue; deduction during the comparison and allocation of the main principles and ways to improve the effectiveness of independent work of students; classification of methods and conditions of independent work; method of comparison of approaches to the theoretical understanding of this problem in the aspect of learning in higher educational institutions (universities); comparison and systematization of research of the chosen problem; description and verbal fixation of research material and results obtained); diagnostic (study independent classroom and extracurricular activities of students, a conversation with future specialists, which indicates the level of development of independence and initiative); empirical (studying the results of the level of independence of students at the University; pedagogical observation in natural conditions of the learning process); experimental (natural experiment); methods of graphic representation of results (histogram or diagram). Borys Grinchenko Kyiv University and National Pedagogical University after M.P. Dragomanov were the experimental base of the study.

The problem was studied in three stages:

1. At the first stage, a theoretical collection and analysis of existing approaches in pedagogy and the education system on the issue of independent work of students, its specifics and problems was carried out; the works of scientists devoted to this problem, its features, approaches to explanation were studied; information data from books, articles, monographs, conferences were considered, in which the features, aspects and ways to increase the effectiveness of individual work were deeply and comprehensively revealed; the principles and levels of this activity were shown (reproductive (training), reconstructive and creative, search); the latest information technology approaches to organizing independent educational work of students were demonstrated various methods and methods for optimizing this process are identified; aspects of successful implementation of this stage of training are presented; conclusions are drawn from the research of scientists; the problem, purpose, forms and methods (methods) of research of the chosen problem are highlighted; a plan for conducting an experimental study is drawn up.

2. At the second stage, research and experimental work were carried out to observe university students in natural 
learning conditions; the importance of developing independence and implementing individual work was considered; the problems that students faced while performing independent work were analyzed; the objective and subjective conditions for organizing independent work were described; the level of development of independent activity in the higher pedagogical education system was diagnosed; the results were revealed based on the conversation and experiment, which helped to identify the features and characteristics of this process; the methods and methods for successful development and conducting independent work were justified; the conclusions obtained during the experimental work were systematized.

3. At the third stage, there was a systematization and classification of the material obtained during the analysis of independent work, Ways and methods of its effective implementation; theoretical, practical conclusions and research results are justified; a comparative analysis of research and approaches to the study of the chosen problem, experiments of scientists who were engaged in considering the issue of students' independence and features of its development was presented; the results of a natural experiment and conversation were generalized and logically presented; the results obtained were classified and graphically presented. In addition, the requirements are presented to increase the creative activity of students and the efficiency of their work, as well as the quality of training.

\section{RESULTS}

\section{Theoretical aspects of the problem of independent work of students}

Independent work of students is an integral part of the educational process. For its successful implementation, it is necessary to adjust and control by teachers, as well as determine the scope of independent work by specialized departments and methodological services of universities. This activity is the planned work of students, which is performed according to certain tasks and under the methodological guidance of the teacher, but without his direct participation.

Self-education should be formed based on modern online technologies, Internet resources, and foreign language proficiency, which will affect the development of motivation, creative skills, and readiness for independent activity [7]. During the educational process, it is important to solve such global tasks as training a motivated specialist; providing students with theoretical knowledge, practical skills; developing information literacy and professional and cognitive skills. To solve these problems successfully, the teacher should change the course of the educational process from the primary transfer of knowledge by the teacher to the teaching methodology, which is based on the analysis of the acquired knowledge and skills through independent work [8]. That is why important attention is paid to optimizing technologies, forms and methods of this activity.

To overcome problems in independent work, students should be more resilient and persistent. In addition, the help of teachers is important. A significant amount of knowledge, skills and abilities of critical perception and analysis are acquired primarily in the process of extracurricular activities, which is an equal form of training [4]. It is worth noting that the effectiveness of such work largely depends on the skillful Organization of the educational process, when students have all the opportunities to realize their own creativity and cognitive activity.

Independent work consists of reproductive and creative processes. There are three main levels of this activity among students: reproductive (training); reconstructive; creative search [9]. The first level contains independent training work that can be performed according to the sample (solving problems, filling out tables). Cognitive activity is manifested in analysis, comprehension, and memorization. The purpose of such tasks is to consolidate knowledge, skills and form new skills. During the second stage (reconstructive independent work), there is an independent change of decisions, drawing up a plan, theses. Reports and abstracts can be used here. Creative independent work represents the third level, which is based on the analysis of the problem situation, obtaining new information. The student must independently choose the forms, means and methods of solving the problem. Types of work are educational and research tasks, term papers and theses.

Scientists note that independent work of students is an important form of the educational process, which is guided by the teacher, and in the process of which creative activity is carried out to consolidate knowledge [10]. Students form new knowledge skills and deepen their scientific worldview, personal beliefs regarding the application of the acquired skills and knowledge in practice. That is why we should not underestimate the importance of individual work of students during the educational process (at lectures, seminars, during practical classes, during extracurricular hours, while performing problem tasks). The main forms of work are preparation and defense of research papers, test papers, course and diploma design, and so on. For effective independent work of students, it is necessary to provide an integrated approach to the organization based on the use of all forms of classroom work; combine all levels of this activity; ensure control over the quality of tasks (consultations).

In the modern interpretation, independent work represents active teaching methods, the unity of Educational, Research, research and practical activities, which are built on close cooperation between the student and the Teacher [1]. Independent work can be classroom and performed during training sessions and extracurricular, which has an individualized and systematic character, which is justified by the process of comprehensive development of the main educational programs and areas of Professional Training [11]. All these types of activities require students to work hard independently, which will contribute to the formation of students' personal ways of organizing professional selfeducation in the future. 


\section{Conditions and methods of organizing independent work of students}

Independent work should be as individualized as possible and have a continuous character that will correspond to a certain stage of mastering one of the main educational programs. It should be included in all processes of educational activities, where the quality and level of self-training of students will help determine the effectiveness of their classroom classes. The increased share of this activity, while strengthening the function of classroom classes, will be one of the areas for improving the educational process. The use of such types of work as scientific research; research papers; scientific reviews in general professional and other disciplines becomes important. Improving the efficiency of organizing independent work of students can be provided using accumulated experience of individual creative activity; a systematic approach to solving the problem in conditions of limited time; a business game; a model of organizing independent work of students [12].

Material and technical support for students' independent work should include the following aspects:

- availability of the required number of classrooms (laboratories, offices with a sufficient number of workplaces, computer classes, places in reading rooms);

- sufficient equipment of classrooms and scientific laboratories with instruments and equipment;

- the existence of documentation that is necessary for individual work.

Educational-methodical and informational support should be responsible for educational literature (textbooks, teaching and visual aids, lecture texts); educational-methodical documentation (data on the organization and planning of independent work of students); examples of tasks and recommendations for their implementation; certain scientific and popular periodicals [13].

The level of Personnel Support must correspond to the University's accreditation. With an increase in the volume of extracurricular activities and independent work of students, the requirements for the professionalism of teachers also increase. As a rule, teachers' value orientations are updated, which are aimed at active participation in educational innovation, self-control and systematic professional development are improved, and so on. The subjective conditions for organizing independent work include the teacher's understanding of the relevance of this type of educational work as a way of forming a person with a high level of social competencies; the teacher's possession of methods and techniques for organizing this process, which should be expressed through high pedagogical skills and personal character traits; the level of general training of students; their awareness of the motives and tasks of independent work, its importance for educational and practical activities.

\section{Research stages and results}

Conducting a scientific experiment provided for the following stages:

- study of literature and research devoted to the problem of independent activity of students; justification of conceptual ideas and methodological principles of its implementation;

- diagnostics of students' level of independence and initiative; demonstration of graphical processing of research results;

- presentation of possible forms and methods of conducting independent work of students.

The study made it possible to identify and analyze the problem of independent work of students, which is quite actively implemented in the educational process of higher educational institutions. The author notes that independence is the ability to see, set and solve a new problem using one's own strength, organizational skills, the ability to plan and anticipate the consequences, the ability to defend one's opinion. In addition, the experiment was based on the observation of future specialists in training and practice. Conversations were also held with teachers regarding the motivation of students to work individually. In total, the study covered 134 students, but the direct participants of the experiment were 94 people who took part in the conversation and study, which helped to identify the level of independence and initiative of students.

Based on the analysis, it can be distinguished that a low level of independence is characterized by the fact that students can perform work only according to the sample. Only $10 \%$ of students had such results. They need to transfer a known method of solving the issue to a similar or remotely similar situation. They do everything based on the example that was previously demonstrated by the teacher. Here, all actions are subordinated to mastering a set of methods of independent activity. In addition, the organization of self-educational activities is random and is generated by the learning process.

The threshold level of independence is typical for students who can perform reconstructive-variable work (31\%). They can transfer knowledge to typical situations, analyze events and facts. Often their self-education activities are not purposeful, but they strive to set goals for themselves. In addition, their motivation is not stable enough, so their individual work is not stable, purposeful and systematic. This group of subjects can independently study educational and scientific literature; prepare abstracts, messages on the topic; take notes; make tables and diagrams; work with regulatory documents using the internet; $46 \%$ of students had an advanced level of independence and were able to write heuristic independent works that contribute to the formation of a creative personality. This group of subjects is characterized by a constant search for new solutions, generalization and systematization of the acquired knowledge, transferring it to completely non-standard situations. These students could easily conduct analytical text processing (writing an abstract, content analysis, compiling a resume, etc.); search for literature and information sources; prepare analytical reviews; model various types of professional activities.

Some students (13\%) had experience writing intrasubject and intersubject research independent works, which 
indicates a high level of independence. To successfully perform this activity, they need to be able to transform and transfer knowledge into practice, develop new ways to solve problems, determine the content, purpose, and develop a plan for solving an educational problem. The main features of these students are that they take an active part in the study of the problem put forward; skillfully use their knowledge, life experience to establish new connections; quickly analyze new connections between objects and phenomena of reality; often seek to formulate a law, instantly identify shortcomings; when solving problems, they offer reasonable ways. They tend to write scientific articles, participate in research work, conferences, competitions, complete term papers and theses, etc. (Fig. 1).

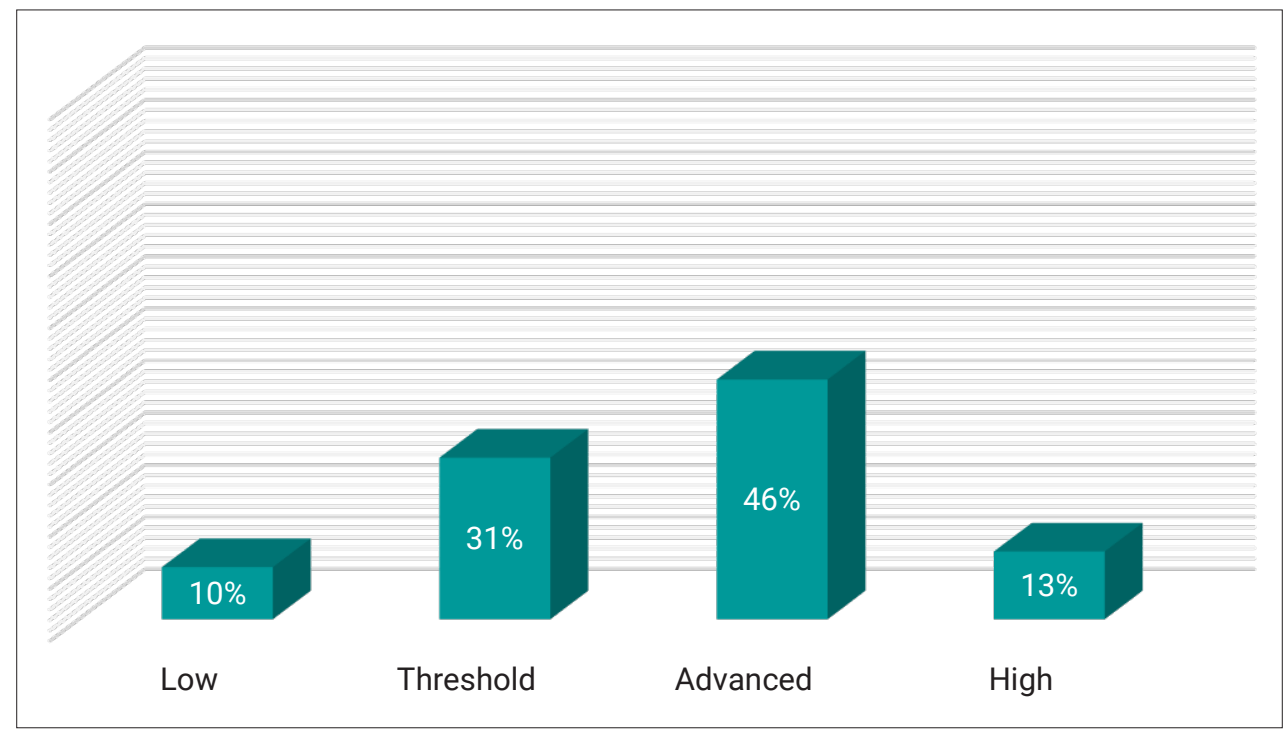

Figure 1. Level of Students' Independence

That is, it can be determined that the majority of students have advanced and threshold levels of independence, which indicates a high-quality educational process and extracurricular activities that affect the effectiveness of students' work and the development of their creative skills.
Forms of Organization of independent learning are manifested at every stage of the educational process, so it is necessary to scientifically justify the forms of independent learning at the University and outside the classroom (Table 1).

Table 1. Forms of independent work of students

\begin{tabular}{c|l}
\multicolumn{1}{c|}{ Form } & \multicolumn{1}{c}{ Main features } \\
Case task & $\begin{array}{l}\text { A problem task where students must understand real professionally-oriented questions. Students } \\
\text { should analyze a large amount of disordered information in a short time. They need to make decisions } \\
\text { when there is a lack of material }\end{array}$ \\
\hline Summary & $\begin{array}{l}\text { The product of independent work of the student, which represents a written summary of the results } \\
\text { of theoretical analysis of a certain scientific (educational and research) topic, where the author must } \\
\text { reveal the content of the problem under study, give various points of view, arguments and his own view } \\
\text { on this issue }\end{array}$ \\
\hline Creative task & $\begin{array}{l}\text { This regulated task has an original solution and helps you identify skills, integrate knowledge from } \\
\text { different industries, and argue your own point of view. It can be performed individually or in a group }\end{array}$ \\
\hline Project work & $\begin{array}{l}\text { A product of independent work of a student who presents a public speech based on the results } \\
\text { of solving a certain educational or research problem }\end{array}$ \\
\hline Presentation & $\begin{array}{l}\text { This type of activity can be grouped or individual. The project itself is created because of planning and } \\
\text { of analytical, research skills, logical and creative thinking skills }\end{array}$ \\
\hline $\begin{array}{l}\text { Presentation of the content of educational material, educational problems using multimedia and } \\
\text { information technologies }\end{array}$
\end{tabular}


Table 1, Continued

\begin{tabular}{c|l}
\hline Form & \multicolumn{1}{c}{ Main features } \\
\hline Essay & $\begin{array}{l}\text { This method allows you to assess the ability of students to present the essence of the problem in } \\
\text { writing, independently analyze it based on deduction and induction. In addition, it is important to use } \\
\text { the concepts and analytical tools of the relevant discipline, which will help to summarize the material } \\
\text { and draw conclusions }\end{array}$ \\
$\begin{array}{c}\text { Information } \\
\text { search }\end{array}$ & $\begin{array}{l}\text { It can be represented by: 1) a bibliographic search for the necessary information about the sources of } \\
\text { information and establishing its presence in the Data System; 2) a search for the information materials } \\
\text { themselves (documents and publications); 3) a search for facts and data in the literature. This form will } \\
\text { help you develop the ability to design and transform learning activities }\end{array}$ \\
\hline Graph diagram & \begin{tabular}{l} 
Graphical display of logical and analytical relationships between text subjects \\
\hline
\end{tabular}
\end{tabular}

Note: the table shows the main forms and methods of individual work of students during educational activities

Source: developed based on the source [14]

The content of extracurricular independent work is formed in accordance with the recommended types of tasks based on the program of the academic discipline. The distribution of time for individual work during the student's day is not regulated by the schedule. Types of tasks for this activity, their content and characteristics can be variable and differentiated, which depends on the specifics of the specialty, discipline and individual characteristics of the student. To increase the creative activity of students and the effectiveness of their work, the quality of training is recommended:

- invite students to study some sections of the course individually;

- give lectures sequentially (by sections and topics) to gradually show new and promising achievements;

- conduct practical classes with elements of a research nature, which will be aimed at solving current, scientific, and technical problems;

- provide students with individual creative tasks;

- create creative groups to solve current production problems with the protection of their proposed developments in production, equate them with course projects and works;

- conduct one final exam for the entire course;

- individual teachers plan to increase the amount of time spent checking their performance;

- from among successful students, create a reserve for completing postgraduate studies [15].

\section{DISCUSSION}

Increasing the requirements for the quality of education is becoming an urgent problem of the modern world and one of the conditions for its development. This is what contributes to the development of an incentive to update its content based on the principles of fundamentality, integrativity and practical orientation. The main task of modern education is further progressive development, which will contribute to the formation of professional competence of a specialist, make him a socially active and creative person. The enormous success of the information education system is based on an increase in the amount of information and, accordingly, the duration of training. The transition to new teaching methods and technologies (computer technologies, trainings, distance learning) will contribute to the qualitative renewal of Education. A negative aspect of university education is the lack of active and individual activity of the student, who is often a passive observer. In the information society, it is important to involve students in independent work. This is what will help to achieve the level of high-quality training of specialists in the context of modernization of education and training technologies, optimization of self-education, self-organization and self-control processes.

Independent learning activity can be described as a process of self-education of students, which is mediated by teachers [2]. A number of criteria can evaluate the effectiveness of organizing independent training. Personal impulses (motivation and guidance) are the main factors of effectiveness. Starting to learn something on their own, students go beyond their needs and set a specific goal. It is then that their cognitive interests are activated, their creative initiative and desire to perform the proposed educational tasks efficiently improves. In addition, it is important to create a semantic and instrumental basis for teaching (formation of students' educational and methodological knowledge; use of methods and techniques for solving a set of educational tasks). No less relevant are educational, cognitive and personality-oriented products of independent learning of students. The criteria for effective organization of independent work are motivational, meaningful, organizational and productive.

To study the impact of independent work on the effectiveness of students' academic work, a study was conducted based on the performance of tests that were supposed to show the level of knowledge acquisition, their consolidation and systematization [16]. Students had to work with the text of textbooks, take notes on lectures, independently study some topics, get acquainted with additional literature, and so on. Then they had to take tests to self-test their knowledge and systematize their skills. Thus, writing tests is a complex individual work. In addition, the quality of the compiled tests was evaluated according to objective criteria. The results showed that students who performed independently performed statistically better on the exam compared 
to the control group. It is also worth noting that the group that successfully wrote the test in the relevant discipline passed the exam better than the students who did not pass the test very well. It is worth noting that, according to the subjective impressions of teachers, the results were excellent. Independent work has become a means of forming general cultural and professional competencies. It has been proven that passing tests is an effective form of their independent work, which improves academic performance and contributes to the formation of general and professional competencies.

Independent work can be divided into classroom and extracurricular activities. Various types of control, creative and practical tasks during a seminar or practical lesson belong to the first type of work. The second type of activity should include performing written homework, analyzing previously listened lecture material in practical classes, preparing a report, performing projects, presentations, and so on. There are five levels of independent work: 1) verbatim and reformation reproduction of Information; 2) performing tasks according to the model; 3) reconstructive work; 4) heuristic tasks; 5) Creative (Research) independent work [17]. The main components of effective individual work are its content, the object of training and the process of educational activity of the teacher. In order for independent work to be effective, you should rely on the specific features of studying the subject. It is important to ensure high motivation of students.

The basis for effective management of independent learning of students in higher educational institutions is to study the didactic conditions of the educational process. Scientists and teachers note that the main difficulties were unclear requirements, lack of special literature, and inconsistency of tasks with the subject of the course. The results of a survey of students on the use of information technologies in performing individual tasks showed that they mainly used lecture notes and electronic resources, rather than textbooks or other educational materials when preparing for classes [18]. They faced such problems as lack of material in books, lack of time, problems with finding information, too much information, which makes it difficult to study. Independent work management should be aimed at improving the efficiency of using Internet resources. That is why the requirements for extracurricular independent work of students were formulated:

- availability of high-quality information and communication learning environment;

- formation of experience in self-education during systematic activities, which gradually turns from direct management of the teacher to self-management;

- the presence of creative elements in the education system;

- cooperation of students during independent work, which increases their motivation, helps them stick to the plan and successfully overcome problems;

- availability of an automated system of pedagogical diagnostics that will help in the design of training;

- careful creation of individual plans and tasks.
Independent work can be carried out in the classroom, where tasks are performed to analyze and consolidate the mentioned topic. Students can also independently master some subjects of the curriculum, complete tasks at home, and prepare for practical classes. Those who study should develop skills that consist in planning independent work, its effective organization, and self-control. If the student can cope with difficulties in the process of acquiring knowledge, as well as at the stage of their application, then creative independence can be developed. It is worth noting that independent work can motivate and become an important stage for Independent Education. Individual activity contributes to the development of one's point of view and attitude to modern realities; it will form a deeper understanding of Educational Sciences, based on which personal life plans and interest are built; it will help to reveal creativity and one's creative talent. Independent education is the main principle of personal development, which characterizes its ability to work independently in future activities. To organize independent training, it is necessary not only to be aware of the importance of a particular profession or field of activity, but also to have certain achievements in this type of activity [19].

Increasing the role of independent work of students in conducting various types of training involves: optimization of teaching methods, introduction of innovations in the educational process, increasing the productivity of the teacher, active use of Information Technologies; introduction of computerized knowledge testing; improvement of research work of students; improvement of the educational institution, the system of course and diploma design, which should improve critical thinking and contribute to the search for ways to solve research problems. An important point is that the organization of independent educational activities through the use of Information Technologies is considered the most effective, but if there is knowledge at the appropriate general scientific and professional levels. Analysis of diagnostic results confirmed the fact that the active use of the electronic information and educational environment affects the skills of independent work [20].

In the pedagogical literature, independent work of students can be considered as a type of educational activity that is carried out without direct intervention of the teacher. In addition, this activity can be defined as a means of attracting students to master the methods of self-education, cognitive activity, and the like. Most scientists analyze the concept of independent work and note that it is a form of educational process in higher educational institutions, which is carried out without outside help [21]. This individual activity can be interpreted as an integral part of the specialist training process, which should include various types of individual and collective educational activities, and can be carried out personally by students in classroom and extracurricular classes.

The organization of independent work is associated with certain pedagogical problems. The research revealed positive aspects and difficulties of independent assimilation 
of knowledge. The following are difficult moments during independent work: lack of balance between the load at the University and independent work; lack of time for a deeper and more meaningful study of the material; inability to organize the daily routine and distribute things; difficult level of tasks; problem in finding suitable materials and sources. On the other hand, the positive aspects are deeper assimilation of the material; meaningful study of literature; formation of an individual approach; development of one's own point of view; obtaining additional information; critical consideration of data, compilation of theses, etc. [21].

In addition, it is worth paying attention to the process of organizing independent work of students using active and interactive technologies using distance educational teaching methods. To solve this issue, a critical analysis of scientific literature, practical experience in organizing training, as well as an analysis of the use of distance educational technologies in the educational process was carried out. The conducted research made it possible to identify three main areas of educational and informational interaction during independent work, namely cloud technologies, social networks and distance educational technologies. The strengths and weaknesses of each direction were identified. At the same time, it was diagnosed that using Distance Education Technologies had many advantages. A survey of 216 first-and fifth-year students of the Stavropol State Pedagogical Institute allowed us to determine the attitude and readiness of students to use distance educational technologies in individual work [22]. The implementation of the project method made it possible to organize a systematic process of project work of students who showed their initiative in planning, organizing and controlling their educational and cognitive activities. It was summarized that the technologies of distance learning systems are sufficient to ensure full-fledged extracurricular work of students and assess the effectiveness of this work. The choice of a particular method or their integration depends on the goals and objectives of training facing the teacher.

A pedagogical study was conducted, and it was determined that $62 \%$ of students do not have the skills to plan and organize independent work; $71 \%$ of them need educational materials for effective activities; $43 \%$ of the subjects do not have enough time for independent work; $6 \%$ are inclined to believe that they can successfully study without daily individual work [23].

To test the effectiveness of independent work, a study was conducted at the Nizhny Novgorod construction technical school during the intermediate certification [24]. Based on the results obtained in the two groups, it was determined that $40 \%$ of students in the first group received an "excellent" grade, $45 \%$ of students received a "good" grade, and 15\% of students received a "satisfactory" grade. The indicators of the second group are more positive. The percentage of students who received an "excellent" grade increased (60\%), which indicates the effectiveness of the developed tasks of independent work. Because of independent work, students developed the following professional competencies: the ability to select building structures and develop details of structural elements; skills in developing architectural and construction drawings using technologies; knowledge of how to perform simple calculations and design building structures.

It can be concluded that independent learning activities develop aspirations, interests; helps students better understand the world, form spiritual needs; promotes their rational and moral-practical activities, which actively affects the aspects of motivation; improves communication skills with others by considering specific conditions and individual characteristics of the team; has a positive impact on the quality and effectiveness of Education.

\section{CONCLUSIONS}

Therefore, it is worth summing up that independent work and ways of its development are an urgent problem of the modern educational process and an integral part of learning. An important goal of independent work is determined by the growing needs of society, which puts forward the need to train a "new type" specialist. This person must be competitive, motivated and ready for continuous development. That is why the training of future professionals is possible only if independent work methods are used in the training process, which will be combined with innovative forms. This process is a cognitive activity, a means of developing such personal and professional traits as: Independence, activity, critical thinking, creative attitude to the perception of information.

The author's words prove that independence is not a static character trait, but refers to the stage of self-realization of the individual, his active activity, which occurs without compulsion. To improve the preparation of students for independent work, it is necessary to conduct an intensification stage, which provides for strengthening the teacher's activity and increasing the activity of students. The article determined that the constant accumulation of experience in independent management of their own educational activities, the development of elements for creativity, the presence of cooperation and communication of students, the use of pedagogical diagnostics, and the design of a system of educational tasks will create high-quality conditions and optimize this stage of training.

The materials of the author's article can be useful for students who want to improve their knowledge, initiative and develop creative independence. In addition, the theoretical data of the article will become relevant for teachers, teachers, and figures of the education system who are trying to optimize the process of independent work and make it more effective. During the research, new questions and problems have emerged that need to be solved. It is worth continuing the research and deepening it, paying attention to studying the requirements for preparing students for self-education, revealing aspects and methods of forming independence, and teaching students forms of professional self-development and self-improvement. The conducted 
research does not claim to be a comprehensive solution to the problem of individual work and its features, so it is planned to continue scientific research in the following areas: improving the content, methods, methods and technologies of introducing independent work into the educational process; attracting teachers and scientists to the development of technologies for independent activity.

\section{REFERENCES}

[1] Samoilenko, I.H, Polesova, T.R., Kryvosheieva, V.V., Chernyshova, O.Ye, Herasymenko, V.V, \& Dolinskyi, V.V. (2021). Independent work of students in the development of professional competence in higher medical educational institutions in the conditions of distance learning. InterConf, 48, 323-332.

[2] Lavrentieva, O.O., Rybalko, L., Tsys, O., \& Uchitel, A. (2019). Theoretical and methodical aspects of the organization of students' independent study activities together with the use of ICT and tools. Educational Dimension, 1(53), 27-59.

[3] Tsyupryk, A. (2004). The results of independent work of students in the study of social sciences. Pedagogic and Psychology of Professional Education, 1, 69-77.

[4] Kartel, T.M. (2006). Independent work of students as a condition of their professional development. Scientific Works, 50(37), 76-81.

[5] Ilyashenko, L.K., Gladkova, M.N., Kutepov, M.M., Vaganova, O.I., \& Smirnova, Z.V. (2019). Development of communicative competencies of students in the context of blended learning. Amazonia Investiga, 8(18), 313-322.

[6] Vaganova, O.I., Konovalova, E.Yu., Abramova, N.S., Lapshova, A.V., \& Smirnova, Z.V. (2019). Increasing the level of teachers' readiness for pedagogical project. Amazonia Investiga, 8(22), 286-294.

[7] Brammer, S., \& Clark, T. (2020). COVID-19 and management education: Reflections on challenges, opportunities, and potential futures. British Journal of Management, 31(3), 453-456.

[8] Bataev, A.V. (2015). Analysis of the global distance education market. Young Scientist, 20(100), 205-208.

[9] Rubanik, A., Bolshakova, G., \& Telnykh, N. (2005). Independent work of students. Higher Education in Russia, 6, 120 -124.

[10] Alkhanov, A. (2005). Independent work of students. Higher Education in Russia, 11, 86-89.

[11] Balychevtseva, I.V., Samoilenko, I.H. Chernyshova, O.Ye., Konyushevska, A.A., Kryvosheieva, V.V., Herasymenko, V.V., Polesova, T.R., Pavlov, E.M., \& Dolynskyi, V.V. (2019). Prospects for implementing distance education at the faculty of postgraduate education. Trauma, 20(4), 131-134.

[12] Slipenka, O.P., \& Kots, I.V. (2006). Improving the quality of independent work of students. Retrieved from http://conf.vntu.edu.ua/humed/2006/txt/06sopsrs.pdf.

[13] Senashenko, V., \& Zhalnina, N. (2006). Independent work of students: Actual problems. Higher Education in Russia, 7, 103-109.

[14] Merenkov, A.V., Kunshchikov, S.V., Hrechukhina, T.I., Usacheva, A.V., \& Vorotkova, I.Yu. (2016). Independent work of students: Types, forms, evaluation criteria. Ekaterinburg: Central Ural Publishing House.

[15] Aleksashin, O.V., \& Honcharuk, H.A. (2018). Independent work of students in the system of educational process. In Quality assurance of higher education: materials of the scientific conference (pp. 252-253). Odesa: ONAFT.

[16] Dyatlova, K.D., \& Kolpakov, I.A. (2012). The experience of forming competences by means of students' individual work. Vestnik of Lobachevsky University of Nizhni Novgorod, 1(1), 25-29.

[17] Abilkhamitkyzy, R., Aimukhambet, Zh.A., \& Sarekenova, K.K. (2014). Organization of independent work of students on credit technology. Procedia - Social and Behavioral Sciences, 143, 274-278.

[18] Kolgatin, O.H., Kolgatina, L.S., Ponomareva, N.S., \& Shmeltser, E. (2019). Systematicity of students' independent work in the cloud learning environment. CEUR Workshop Proceedings, 2433, 184-196.

[19] Muratov, Kh.H. (2019). Implementation of independent educational activities of students. European Journal of Research and Reflection in Educational Sciences, 7(12), 25-28.

[20] Zhestkova, E., \& Fomina, N. (2019). Electronic information and educational environment of the university as a means of organizing independent work of students. Environment. Technologies. Resources, 2, 247-252.

[21] Kolisnyk, Ya., \& Tsybulyak, B. (2009). Organizing students' individual work in credit-module system of education. Visnyk of the Lviv University. Series Pedagogics, 25(2), 332-341.

[22] Maliataki, V.V., Kirichek, K.A., \& Vendina, A.A. (2020). Distance learning technologies as a modern resource of implementing active and interactive methods of education for the organizing of independent work of students. Open Education, 24(3), 56-66.

[23] Sikorskyi, P., \& Horina, O. (2008). Psychological and pedagogical issues of improving the efficiency of students' individual work. Visnyk of the Lviv University. Series Pedagogics, 23, 46-54.

[24] Vaganova, O., Odarich, I., Popkova, A., Smirnova, Zh., \& Lebedeva, A. (2019). Independent work of students in professional educational institutions. Amazonia Investiga, 8(22), 295-304. 


\title{
Лілія Василівна Гузар
}

Київський національний університет імені Тараса Шевченка

01033, вул. Володимирська, 60, м. Київ, Україна

\section{Ефективність самостійної роботи студентів: проблема та шляхи покращення}

\begin{abstract}
Анотація. Актуальність дослідження зумовлена тим, що в сучасному суспільстві важливою постає проблема виховання професіоналів і спеціалістів, які володіють здатністю мислити критично та самостійно. Кількість інформації та знань, які має засвоїти студент, збільшується. У вищих навчальних закладах виникає об’єктивна потреба приділяти більше уваги самостійній роботі студентів, щоб сприяти їхному ефективному та результативному професійному становленню. Щоб зберегти та підвищити ефективність навчання, освітні установи мають прагнути до пошуку нових способів використання навчального процесу для організації самостійної роботи студентів. У зв'язку з цим стаття автора спрямована на визначення сутності та особливостей самостійної роботи студентів, шляхів іiі впровадження та принципів підвищення результативності у вищих навчальних закладах. Провідними методами дослідження цієї проблеми є методи аналізу, синтезу, дедукції, узагальнення та зіставлення, що допомогли визначити основну суть самостійної роботи студентів і проблеми цієї складової навчання. У статті наведено різноманітні підходи до вивчення та тлумачення процесу самостійної роботи студентів; проведено аналіз робіт викладачів, дослідників, які займаються проблемою мотивації та підвищення ефективності цього виду діяльності; акцентовано увагу на труднощах та особливостях іiі організації; запропоновано різноманітні методи та способи оптимізації цього процесу; описано аспекти вдалого здійснення цього етапу навчання; діагностовано проблеми, з якими студент стикається під час виконання самостійної роботи; визначено рівні цієї діяльності (репродуктивний (тренувальний), реконструктивний та творчо-пошуковий); продемонстровані новітні інформаційно-технологічні підходи до організації самостійної навчальної діяльності студентів; діагностовано ефективність самостійної роботи у процесі навчання на основі засвоєння навчального матеріалу, моніторингу навчальної та пізнавальної діяльності студентів; розкрито рекомендації та вимоги щодо підвищення ефективності самостійної роботи. Матеріали статті представляють практичну та теоретичну цінність для студентів, оскільки сприяють розвитку їхньої ініціативності та професійної самостійності. Крім того, інформація може бути актуальною для майбутніх педагогів, науковців, викладачів, які зможуть регулювати завдання відповідно до індивідуальних особливостей тих, хто навчається, та систематично контролювати освітній процес
\end{abstract}

Ключові слова: професійний розвиток, ініціативність, позааудиторна самостійна робота, творча самостійна робота, самостійність 